\title{
Glosa do wyroku Trybunału Sprawiedliwości Unii Furopejskiej z dnia 12 lutego 2015 r. w sprawie Sähköalojen ammattiliitto ry c/a Elektrobudowa Spółka Akcyjna (C-396/13)
}

\begin{abstract}
This paper aims to comment an important ruling concerning the Posted Workers Directive (Directive 96/71/EC). In the judgement C-396/13 (Sähköalojen ammattiliitto ry v. Elektrobudowa Spółka Akcyjna), the European Court of Justice provided its pro-worker's interpretation of Art 3 of Directive 96/71/EC concerning the scope of the „minimum pay rate”. The second issue raised by the European Court of Justice was the assignability of pay claims governed by Polish law based on Art 14 (2) of Rome I Regulation and prohibited under that law. In commented judgement, the Court admitted the assignment of claims arising from employment relationships in light of article 47 of the Charter of Fundamental Rights of the European Union and accepted the trade union's right to represent the posted workers.
\end{abstract}

Keywords: posted workers, freedom of movement for workers, law applicable to individual employment contracts, assignment of pay claims, Rome I Regulation, Directive 96/71/EC

Za poszerzoną analizą wyroku Trybunału Sprawiedliwości UE w sprawie Sähköalojen ammattiliitto ry c/a Elektrobudowa Spótka Akcyjna (C-396/13) przemawiaja przynajmniej dwa argumenty. Po pierw-

a) Dr hab., Uniwersytet Śląski w Katowicach. 
sze, dotyczy on polskiego podmiotu, co może samo w sobie nie miałoby większego znaczenia gdyby nie fakt, że to polscy przedsiębiorcy najczęściej wykonują usługi w Unii Europejskiej dzięki pracownikom delegowanym. Dlatego też rozstrzygnięcie wątpliwości, jakie pojawiają się na tle stosowania dyrektywy $96 / 71 / \mathrm{WE}^{1}$, ma znaczenie dla szerokiej grupy naszych pracodawców. Nie bez znaczenia pozostaje także fakt, że orzeczenie to uwzględnia lokalny kontekst i oparte jest na polskich przepisach prawa. Po drugie, omawianym rozstrzygnięciem Trybunał Sprawiedliwości UE dokonuje na nowo, przynajmniej w odniesieniu do niektórych zagadnień, wykładni regulacji poświęconych pracownikom delegowanym w kierunku bardziej propracowniczym niż mogłoby to wynikać wprost z treści tego aktu, torując drogę nowelizacji dyrektywy 96/71/ WE ${ }^{2}$, która $\mathrm{w}$ jeszcze większym stopniu będzie chronić interesy pracowników delegowanych, kosztem ich pracodawców.

Analiza wskazanego w tytule wyroku Trybunału Sprawiedliwości UE powinna być poprzedzona przynajmniej skrótowym omówieniem stanu faktycznego, który stał się podstawą tego rozstrzygnięcia.

Elektrobudowa S.A. zawarła ze swoim fińskim kontrahentem umowę, na podstawie której zobowiązała się do wykonania prac przy budowie elektrowni jądrowej w Finlandii. Usługi te były wykonywane przez polskich pracowników delegowanych do pracy w fińskim oddziale tej spółki, a ich umowy o pracę podlegały prawu polskiemu. Elektrobudowa S.A. zakwaterowała zatrudniane przez siebie osoby w odległości około piętnastu kilometrów od miejsca pracy. W związku z występującymi rozbieżnościami pomiędzy polskim i fińskim prawem okazało się, że pracownicy delegowani niezgodnie z prawem fińskim (obejmujacym także układy zbiorowe pracy uzgodnione dla sektora elektryfikacji) nie otrzymywali dodatku wakacyjnego, stałej diety przysługujaccej oddelegowanym poza miejsce zamieszkania, świadczenia związanego z kosztami zakwaterowania, jak również „odszkodowania” związanego z koniecznością codziennej podróży do pracy. Poza kwestionowaniem podstaw do wypłaty wskazanych świadczeń dodatkowych Elektrobudowa S.A. naruszyła prawo fińskie poprzez uniemożliwienie pracownikom pracy w systemie akordowym, dzięki czemu mogliby oni uzyskać wyższe wynagrodzenie, $\mathrm{w}$ tym dodatek gwarantowany za prace na akord. Wynikało to po części z przyporządkowania polskich pracowników do grup zaszeregowania

${ }^{1}$ Dyrektywa 96/71/WE Parlamentu Europejskiego i Rady z dnia 16 grudnia 1996 r. dotycząca delegowania pracowników w ramach świadczenia usług (Dz.Urz. L 018, 21/01/1997, s. 1-6) [dalej: dyrektywa 96/71/WE].

${ }_{2}^{2}$ Zob. dyrektywę Parlamentu Europejskiego i Rady (UE) 2018/957 z dnia 28 czerwca 2018 r. zmieniajaccą dyrektywę 96/71/WE dotyczącą delegowania pracowników w ramach świadczenia usług (Dz. Urz. L 173, 9/07/2018, s. 16-24). 
w myśl polskich przepisów, a nie według reguł wynikających z fińskich układów zbiorowych pracy ${ }^{3}$.

Wskazane powyżej naruszenia prawa pracy miały uzasadniać główny zarzut polskich pracowników zatrudnionych przez Elektrobudowę S.A. sprowadzający się do twierdzenia, że nie otrzymali oni za okres pracy za granica minimalnego wynagrodzenia, obliczonego zgodnie z fińską ustawą o pracownikach delegowanych. W celu wystąpienia z powództwem do sądu w Finlandii pracownicy delegowani dokonali cesji swych roszczeń o wypłatę spornej części wynagrodzenia za pracę na reprezentującą ich w relacji z pracodawca fińska organizacja związkowa.

Elektrobudowa S.A. nie podzieliła stanowiska Sähköalojen ammattiliitto ry $\mathrm{w}$ zakresie niewywiązywania się z obowiązku wypłaty na rzecz swoich pracowników wynagrodzenia minimalnego, o którym mowa w art. 3 ust. 1 lit. c) dyrektywy 96/71/WE, zarzucając przy tym brak legitymacji procesowej związku zawodowego do występowania w postępowaniu sądowym z powodu nieskuteczności przelewu wierzytelności pracowniczych, dokonanego z naruszeniem zakazu wynikajacego z art. 84 polskiego kodeksu pracy ${ }^{4}$.

Na tle tak zarysowanego stanu faktycznego pojawiły się dwa zagadnienia prawne, które znalazły swoje rozstrzygnięcie w omawianym orzeczeniu Trybunału Sprawiedliwości UE. Zagadnienia te można przedstawić za pomoca dwóch pytań. Po pierwsze, czy za skuteczną można uznać cesję dokonaną przez pracowników Elektrobudowy S.A. na rzecz związku zawodowego (a zatem - czy ten ostatni jest legitymowany do wystąienia z powództwem o zapłatę) oraz, po drugie, czy świadczenie, jakie pracownicy delegowani otrzymywali, wykonując swoje obowiazki w Finlandii, stanowiło wynagrodzenie minimalne określone na podstawie fińskich układów zbiorowych pracy powszechnie stosowanych (o których mowa w art. 3 ust. 8 dyrektywy 96/71/WE).

W odniesieniu do pierwszej kwestii Trybunał Sprawiedliwości UE uznał, że wynikające z art. 84 k.p. ograniczenie dopuszczalności cesji wierzytelności o zapłatę wynagrodzenia jest sprzeczne z art. 47 Karty praw podstawowych Unii Europejskiej ${ }^{5}$, a w związku z tym brak jest przeszkód, by Sähköalojen ammattiliitto ry — działając jako cesjonariusz

${ }^{3}$ Szerzej stan faktyczny sprawy został omówiony przez M. Zachariasiewicza, W: System prawa prywatnego. Tom 20B. Prawo prywatne międzynarodowe, Red. M. Pazdan. Warszawa 2015, s. 523 oraz W. Ku row skiego: Stosunek pracy wynikajacy z umowy $w$ prawie prywatnym międzynarodowym. Warszawa 2016, s. 235-236.

${ }^{4}$ Ustawa z dnia 26 czerwca 1974 r. — Kodeks pracy (t.j. Dz.U. z 2019 r., poz. 1040 ze zm.) [dalej: k.p.].

${ }^{5}$ Karta praw podstawowych Unii Europejskiej (Dz.Urz. C 326, 26/10/2012, s. 391407) [dalej: Karta Praw Podstawowych]. 
— wytoczył powództwo o zapłatę przed sąd państwa, w którym takie przeniesienie wierzytelności jest dopuszczalne.

Biorąc pod uwage okoliczności sprawy należy jednak stwierdzić, że o ile konkluzja Trybunału Sprawiedliwości UE jest słuszna, a zatem fiński związek zawodowy skutecznie nabył będące przedmiotem sporu wierzytelności pracownicze ${ }^{6}$ i mógł wytoczyć powództwo o zapłatę, o tyle uzasadnienie prawne tej tezy jest — jak się wydaje - chybione.

W uzasadnieniu swojego stanowiska Trybunał Sprawiedliwości UE uznał, że wypływające $\mathrm{z}$ art. 47 Karty praw podstawowych prawo do skutecznego środka prawnego i dostępu do bezstronnego sądu zostałoby naruszone, gdyby w sprawie znalazł zastosowanie przepis art. 84 k.p., wprowadzajacy ustawowy zakaz cesji wierzytelności o wynagrodzenie za pracę i powodujący nieskuteczność przeniesienia tych należności na związek zawodowy. W konsekwencji bowiem Sähköalojen ammattiliitto ry nie przysługiwałaby legitymacja do wytoczenia powództwa o zapłatę, a zatem organizacja ta pozbawiona byłaby skutecznego środka do obrony praw pracowniczych. Innymi słowy, wynikajace z polskiej regulacji prawa pracy wyłączenie możliwości rozporządzenia wynagrodzeniem za pracę na osobę trzecią nie tylko nie zabezpiecza interesów pracowniczych (co stało u podstaw uzasadnienia dla tej regulacji — o czym niżej), ale stanowi wprost naruszenie fundamentalnych zasad, na których opiera się prawo Unii Europejskiej (wpisanych wprost do Karty praw podstawowych).

Rozważania odnoszące się do słuszności tezy Trybunału Sprawiedliwości UE musi poprzedzić analiza art. 47 Karty praw podstawowych. Zgodnie ze wskazanym przepisem każdy, kogo prawa i wolności zagwarantowane przez prawo Unii Europejskiej zostały naruszone, ma prawo do skutecznego środka prawnego przed sądem, jak również do sprawiedliwego i jawnego rozpatrzenia jego sprawy w rozsądnym terminie przez niezawisły i bezstronny sąd, ustanowiony uprzednio na mocy ustawy oraz do uzyskania porady prawnej, skorzystania z pomocy obrońcy i przedstawiciela, w przypadku osób niezamożnych — nieodpłatnie. Wskazana regulacja dotyczy wprost tzw. prawa do sądu, które w granicach $\mathrm{w}$ tym przepisie określonych, powinno być uregulowane $\mathrm{w}$ prawie krajowym. Tymczasem nie sposób uznać, że zakaz dokonywania cesji wierzytelności o wynagrodzenie za pracę ogranicza pracownikowi prawo do sądu; co więcej, Trybunał Sprawiedliwości UE nie wyjaśnił na czym to ograniczenie miało polegać 7 . Co prawda, można przyjąć założenie, że

${ }^{6}$ Odmiennie P. Wąż: Glosa do wyroku TS z dnia 12 lutego 2015 r., C-396/13. LEX/ el. 2015 , pkt 6 .

${ }^{7}$ Tak też P. Wąż: Glosa do wyroku TS z dnia 12 lutego 2015 r., C-396/13, LEX/el. 2015 , pkt 6 . 
polskiemu pracownikowi trudniej niż fińskiej organizacji związkowej byłoby wytoczyć powództwo w Finlandii, jednakże pozew w tej sprawie mógł być wniesiony bez przeszkód do sądu polskiego na podstawie art. 19 ówcześnie stosowanego rozporządzenia jurysdykcyjnego ${ }^{8}$. Zasadny byłby także argument, że $\mathrm{w}$ związku $\mathrm{z}$ istniejącym $\mathrm{w}$ ramach stosunku pracy zwierzchnictwem, pracownicy Elektrobudowy S.A. mogli się obawiać występowania osobiście z powództwem przeciwko swojemu pracodawcy, stąd też posłużenie się przez nich konstrukcją cesji wierzytelności na Sähköalojen ammattiliitto ry, pozwalało uniknacc niekomfortowej dla nich sytuacji. Jednakże wskazany cel mógł równie dobrze być osiagnięty poprzez ustanowienie przez pracowników pełnomocnika w osobie przedstawiciela organizacji związkowej ${ }^{9}$, reprezentującego ich $\mathrm{w}$ sporze z pracodawca. Nie sposób zatem znaleźć obiektywnie istotnego argumentu przemawiającego za teza, zgodnie z którą wyłączenie dopuszczalności zbycia wierzytelności o wynagrodzenie za prace (w tym na rzecz organizacji związkowej zrzeszającej danego pracownika) prowadzi do ograniczenia zatrudnionemu prawa do sądu ${ }^{10}$.

Tymczasem ratio legis reguły wynikajacej z art. 84 k.p. jest zupełnie inna i stanowi przejaw ochrony szeroko rozumianych praw pracowniczych, o czym Trybunał Sprawiedliwości UE w uzasadnieniu glosowanego orzeczenia nawet nie wspomniał. U podstaw regulacji wynikającej z art. 84 k.p. legły bowiem zasady kierunkowe konwencji Nr 95 Międzynarodowej Organizacji Pracy dotyczącej ochrony płacy ${ }^{11}$. Ich wdrożenie przez poszczególnych prawodawców miało na celu zapewnienie pracownikom prawnej ochrony wynagrodzenia za pracę. Poprzez przyjęcie konwencji Nr 95 MOP poszczególne państwa zobowiązały się takiego ukształtowania własnego systemu prawa, by zrealizować cel konwencji, jakim jest zapewnienie pracownikom możliwości uzyskania realnych

${ }^{8}$ Zob. art. 19 pkt 1 rozporządzenia Rady (WE) nr 44/2001 z dnia 22 grudnia 2000 r. $\mathrm{w}$ sprawie jurysdykcji i uznawania orzeczeń sądowych oraz ich wykonywania w sprawach cywilnych i handlowych (Dz.Urz. L 012, 16/01/2001, s. 1-23).

${ }^{9}$ Zob. art. $465 \S 1$ k.p.c., zgodnie z którym pełnomocnikiem pracownika [...] może być również przedstawiciel związku zawodowego lub inspektor pracy albo pracownik zakładu pracy, w którym mocodawca jest lub był zatrudniony [...].

${ }_{10}$ Zob. tė̇ P. Wą̇̇: Glosa do wyroku TS z dnia 12 lutego 2015 r., C-396/13, LEX/el. 2015 , pkt 6 .

${ }^{11}$ Konwencja Nr 95 MOP z 1.7.1949 r. dotycząca ochrony płacy (Dz.U. z 1955 r. Nr 38, poz. 234 zał.) [dalej: konwencja Nr 95 MOP]. Zob. w szczególności: W. Kurowski: Dopuszczalność zajęcia oraz przelewu wierzytelności o wynagrodzenie za pracę. Uwagi na tle wyroku Trybunału Sprawiedliwości Unii Europejskiej w sprawie Sähköalojen ammattiliitto ry v. Elektrobudowa SA, w: Prawo prywatne wobec wyzwań współczesności. Księga pamiatkowa dedykowana Profesorowi Leszkowi Ogiegle, Red. M. Fras, P. Ślęzak. Warszawa 2017, s. 231-233. 
środków potrzebnych do własnego utrzymania. W kontekście glosowanego orzeczenia Trybunału Sprawiedliwości UE na szczególną uwage zasługuje wynikajacca z art. 10 konwencji Nr 95 MOP dyrektywa ograniczenia dopuszczalności przelewu wierzytelności o wynagrodzenie za pra$c^{12}$. W myśl tego przepisu „płacę należy chronić od [...] cesji w stopniu uznanym za potrzebny dla zapewnienia utrzymania pracownika i jego rodziny". Jednocześnie zakres ochrony i sposób, w jaki dyrektywa ta zostanie implementowana do prawodawstwa wewnętrznego oddano ustawodawcom krajowym. Ci ostatni zostali bowiem zobowiązani do określenia „trybu” i „granic” (dopuszczalności) przenoszenia wierzytelności o wynagrodzenie za pracę. Zadaniu temu sprostał polski prawodawca poprzez regulację wynikająca z art. 84 k.p. ${ }^{13}$. W polskiej judykaturze, jak i w wypowiedziach doktryny próżno szukać poglądów kwestionujacych zasadność wskazanego unormowania. Zważywszy bowiem na rangę Międzynarodowej Organizacji Pracy oraz fakt pionierskiej regulacji propracowniczej wynikającej z konwencji Nr 95, która stała się podstawą opisanego polskiego unormowania, nie sposób przypisywać temu ostatniemu celów sprzecznych z interesem pracowników ${ }^{14}$.

Wprowadzony art. 84 k.p. zakaz przenoszenia wierzytelności o wynagrodzenie za prace ma charakter bezwzględny i nie sa przewidziane od niego wyjątki. Chodzi bowiem o uniknięcie sposobności do obejścia tego ograniczenia. Dotyczy on zatem także cesji na rzecz organizacji zwiąkowej, którego to przelewu próbowali dokonać pracownicy Elektrobudowy S.A. W przypadku zawarcia umowy przeniesienia wierzytelności pracowniczych, o których mowa w art. 84 k.p., pożądany przez strony skutek nie nastąpi, gdyż na podstawie przepisów art. 58 k.c. w zw. z art. 300 k.p., umowę należy uznać za nieważna. Uprawnionym do otrzymania wynagrodzenia za prace pozostanie zatem dalej pracownik.

Trybunał Sprawiedliwości UE nie podjął się jednak ważenia interesów stron, które sa chronione odpowiednimi regulacjami o charakterze ponadkrajowym, a wynikaja z art. 10 konwencji Nr 95 MOP (w zakresie ochrony wynagrodzenia za pracę) oraz z art. 47 Karty praw podstawowych (co do zapewnienia prawa do sądu). Zarówno bowiem w odniesieniu do pierwszego, jak i drugiego wskazanego wyżej ważkiego interesu, w tej konkretnej sprawie znalazły by się argumenty przemawiajace za pryma-

${ }^{12}$ Zob. także W. Kurowski: Wynagrodzenie za pracę $i$ jego ochrona w prawie prywatnym międzynarodowym, w: Rozprawy z prawa prywatnego. Księga jubileuszowa dedykowana Profesorowi Wojciechowi Popiotkowi, Red. M. Pazdan, M. Jagielska, E. Rott-Pietrzyk, M. Szpunar. Warszawa 2017, s. 89-90.

${ }^{13} \mathrm{Na}$ ten temat zob. W. Kurowski: Dopuszczalność..., s. 235-236.

${ }^{14}$ W. Kurowski: Stosunek pracy..., s. 301-303. 
tem jednej ${ }^{15}$ albo drugiej regulacji ${ }^{16}$, a co za tym idzie - zastosowaniem względnie odmówieniem zasadności stosowania art. 84 k.c.

Poczynione powyżej uwagi nie moga jednak przesłonić głównego zarzutu, jaki należy skierować w odniesieniu do komentowanego orzeczenia (a właściwie - jego uzasadnienia). Właściwa kolizyjnoprawna ocena przez Trybunał Sprawiedliwości UE dokonanego przez pracowników Elektrobudowy S.A. na rzecz Sähköalojen ammattiliitto ry przelewu wierzytelności o wynagrodzenie za pracę (a precyzyjniej - części tego świadczenia) pozwoliłaby bowiem na uznanie cesji - w tym konkretnym stanie faktycznym - za ważna, bez uciekania się do podważania propracowniczego zakazu cesji wypływającego z art. 84 k.p. ${ }^{17}$.

Na wstępie należy wskazać, że przelew wierzytelności o wynagrodzenie za pracę nie wchodzi w zakres statutu stosunku pracy (wyznaczanego przepisami art. 8 rozporządzenia Rzym I) i wymaga odrębnej kolizyjnoprawnej oceny $\mathrm{w}$ oparciu o miarodajne reguły wypływające $\mathrm{z}$ art. 14 rozporządzenia ${ }^{18}$. W myśl generalnej reguły z art. 14 ust. 1 tego aktu,

${ }^{15}$ Pracownicy Elektrobudowy S.A. mieli możliwość wytoczenia powództwa o zapłatę części wynagrodzenia (do kwoty wynagrodzenia minimalnego) zarówno w Polsce (na podstawie ), jak i w Finlandii. Nie musieli także czynić tego samodzielnie, gdyż ich interesy mógł reprezentować m.in. przedstawiciel związku zawodowego, a zatem zbędne było dokonywane przelewu spornych wierzytelności na organizację związkową. Bez uszczerbku dla propracowniczej regulacji wynikającej z art. 84 k.p. prawo do sądu w odniesieniu do tych pracowników nie zostało naruszone (a zatem zasada wypływajacca z art. 47 Karty praw podstawowych została naruszona).

${ }^{16} \mathrm{~W}$ omawianej sytuacji faktycznej nie istniało ryzyko naruszenia szeroko rozumianego prawa pracownika do wynagrodzenia za pracę. Przelew wierzytelności na rzecz organizacji związkowej miał na celu umożliwienie ich dochodzenia przez cesjonariusza, bez uszczerbku interesom cedentów. Sähköalojen ammattiliitto ry działał bowiem formalnie jako uprawniony, ale nie budzi wątpliwości, że rzeczywistymi beneficjentami postępowania sądowego byli pracownicy Elektrobudowy S.A., którzy mieli uzyskać całość zasądzonych kwot. Jednocześnie pracownicy ci zyskiwali na profesjonalnym podejściu organizacji związkowej do sprawy i unikali niekomfortowej sytuacji prowadzenia sporu z własnym pracodawcom. Można zatem uznać, że bezwzględny zakaz cesji wierzytelności o wynagrodzenie za pracę wypływający z art. 84 k.p. jest zbyt daleko idący, a cel regulacji art. 10 konwencji Nr 95 MOP (w zakresie ochrony wynagrodzenia za pracę) można osiągnąc środkami mniej dla pracowników uciążliwymi. Warto zatem uczynić w tym zakresie wyjątek podmiotowy (umożliwiający cesję na rzecz określonych podmiotów, przykładowo - organizacji związkowych) oraz rodzajowy (stwarzający podstawy prawne jedynie dla przelewu w celu inkasa, stanowiącego rodzaj cesji powierniczej, z wyłączeniem wynagrodzenia dla świadczącego usługi windykacyjne).

${ }^{17}$ Odmiennie P. Wą̇̇: Glosa do wyroku TS z dnia 12 lutego 2015 r., C-396/13, LEX/ el. 2015 , pkt 6 .

${ }^{18}$ M.P. Zachariasiewicz: Zmiany $w$ unormowaniu cesji wierzytelności (od artykutu 12 konwencji rzymskiej do artykułu 14 rozporzqdzenia Rzym I), „Problemy Prawa Prywatnego Międzynarodowego" [dalej: PPPM] 2010, T. 6, s. 115-154; A. Wowerka: Przelew wierzytelności w świetle rozporzqdzenia Rzym I, PPPM 2011, T. 9, s. 35-61; 
stosunek między zbywcą i nabywcą wierzytelności podlega prawu, które zgodnie z rozporządzeniem jest właściwe do oceny umowy zawartej między nimi ${ }^{19}$. Jednocześnie zgodnie $\mathrm{z}$ art. 14 ust. 2, prawo, któremu podlega przenoszona wierzytelność, rozstrzyga o jej zbywalności, stosunku pomiędzy nabywcą wierzytelności a dłużnikiem, przesłankach skuteczności przelewu wobec dłużnika oraz zwalniającym skutku świadczenia przez dłużnika. Ocena dopuszczalności przeniesienia danej wierzytelności (tj. ustalenie, czy w odniesieniu do niej przewidziane sa ograniczenia albo bezwzględny zakaz cesji) podlega prawu dla niej właściwemu ${ }^{20}$. Skoro w sprawie Sähköalojen ammattiliitto ry przeciwko Elektrobudowie S.A. przedmiotem sporu była wierzytelność o wynagrodzenie za pracę, miarodajnego dla niej statutu należy poszukiwać w oparciu o art. 8 rozporządzenia Rzym I, wskazującego prawo właściwe dla stosunku pracy, z którego ona wynika. Trzeba jednak pamiętać, że w tym konkretnym przypadku, zważywszy na to, że chodziło o wynagrodzenie za pracę pracowników delegowanych, należy przy ustalaniu właściwej legis causae uwzględnić także regulację wypływajacca z art. 3 ust. 1 lit. c dyrektywy 96/71/WE. Mimo zatem, że co do zasady umowy o pracę pracowników Elektrobudowy S.A. podlegały prawu polskiemu (strony stosunku pracy dokonały bowiem wyboru tego właśnie prawa), to na podstawie wskazanego przepisu dyrektywy 96/71/WE, będąca przedmiotem sporu część wynagrodzenia nie podlegała prawu polskiemu, a - fińskiemu ${ }^{21}$. Cesją objęte były bowiem jedynie te składniki (elementy) wierzytelności, które

W. Kurowski: Nowe kolizyjnoprawne unormowanie podmiotowych zmian stosunku zobowiazaniowego na tle rozporzadzenia „Rzym I" $i$ polskiej ustawy - Prawo prywatne międzynarodowe z 2011 r., w: Wspótczesne wyzwania prawa prywatnego międzynarodowego, Red. J. Poczobut. Warszawa 2013, s. 143-147; W. Kurowski: Zmiany podmiotowe, w: System Prawa Handlowego, t. 9. Międzynarodowe prawo handlowe, Red. W. Popiołek. Warszawa 2013, s. 766-769.

${ }_{19}$ M.P. Zachariasiewicz: Zmiany w unormowaniu..., s. 145-146; A. Wowerka: Przelew wierzytelności..., s. 40-42; W. Kurowski: Nowe kolizyjnoprawne unormowanie..., s. 143-144; M. Czepelak: Międzynarodowe prawo zobowiazań Unii Europejskiej. Komentarz do rozporzadzeń rzymskich. Warszawa 2012, s. 417-420; W. Kurowski: Zmiany podmiotowe..., s. 766-767; W. Kurowski, w: Prawo Prywatne Międzynarodowe. Komentarz, Red. M. Pazdan. Warszawa 2018, s. 792-793.

20 T.C. Hartley: Choice of law regarding the voluntary assignment of contractual obligations under the Rome I regulation, „International and Comparative Law Quarterly" [dalej: ICLQ] 2011, Nr 1, s. 37; W. Kurowski: Zmiany podmiotowe..., s. 768; W. Kurowski, w: Prawo..., s. 795-796; W. Kurowski: Wynagrodzenie..., s. 91.

${ }^{21}$ W. Kurowski: Dopuszczalność..., s. 239-240. Odmiennie P. Wąż: Glosa do wyroku TS z dnia 12 lutego 2015 r., C-396/13, LEX/el. 2015, pkt 6. Odmiennie również co do zasady TSUE, choć w uzasadnieniu brak jest wyraźnego stanowiska tego sądu, wyrażonego expressis verbis. Zob. uzasadnienie wyr. TSUE z 12.2.2015 r., C-396/13, Sähköalojen ammattiliitto ry $v$. Elektrobudowa S.A., pkt 19-26. 
stanowiły uzupełnienie minimalnego wynagrodzenia przysługującego uprawnionym na podstawie prawa obowiązującego w Finlandii. Przyjmując zatem, że przedmiotem przelewu stały się składniki należności pracowników poddane prawu fińskiemu, to w tym ostatnim systemie prawnym należy poszukiwać odpowiedzi na pytanie o dopuszczalność ich przeniesienia na osobę trzecia ${ }^{22}$. Decyduje zatem prawo, któremu poddane sa przenoszone uprawnienia w ramach wierzytelności o wynagrodzenie za pracę $e^{23}$.

Tymczasem, zgodnie z $\S 7$ rozdziału 1 fińskiej ustawy o umowie o pracę ${ }^{24}$, ograniczenia zbywalności odnoszą się tylko do niewymagalnych wierzytelności wynikających z umowy o pracę (ust. 2). Zważywszy, że cesja na rzecz Sähköalojen ammattiliitto ry objęte zostały wymagalne należności polskich pracowników, to przyjmując w tym zakresie właściwość prawa fińskiego, przeniesienie wierzytelności było skuteczne. Innymi słowy, umowa przelewu wierzytelności pracowników Elektrobudowy S.A. - wbrew stanowisku Trybunału Sprawiedliwości UE - wywołała skutek bez konieczności podważania legalności regulacji wynikajacej z art. 84 k.p., w oparciu o jego sprzeczność z art. 47 Karty praw podstawowych, a uprawnionym do dochodzenia już swoich należności stała się organizacja związkowa. Sähköalojen ammattiliitto ry była zatem legitymowana do wytoczenia przeciwko Elektrobudowie S.A. powództwa i w tym zakresie rozważania Trybunału Sprawiedliwości UE odnoszące się do rzekomego naruszania przez art. 84 k.p. zasady prawa do sądu, wynikajacej z Karty praw podstawowych, nie były celowe.

Omówienie pierwszej kwestii, kluczowej ze względu na ustalenie legitymacji procesowej powoda w postępowaniu, umożliwia bliższe przyjrzenie się drugiemu zagadnieniu prawnemu podjętemu przez Trybunał Sprawiedliwości UE, zarysowanemu na wstępie glosy. Odpowiedzi wymaga zatem pytanie, na ile świadczenie wynikajace $\mathrm{z}$ umowy o pracę, które pracownicy Elektrobudowy S.A. otrzymywali w zamian za wyko-

${ }^{22}$ Przepis art. 3 ust. 1 lit. c dyrektywy 96/71/WE stanowi wyjatek od unormowania art. 8 rozporządzenia Rzym I.

${ }^{23}$ Należy podkreślić, że przedmiotem przelewu na rzecz Sähköalojen ammattiliitto ry były jedynie poszczególne uprawnienia (elementy wierzytelności o wynagrodzenie za pracę) podlegające - co oczywiste w kontekście sprawy, na podstawie art. 3 ust. 1 dyrektywy 96/71/WE - prawu fińskiemu (na istnienie tych bowiem uprawnień w prawie fińskim, kształtujących minimalne wynagrodzenie za pracę, zwracał uwage powodowy związek zawodowy). Na podstawie art. 14 ust. 2 rozporządzenia Rzym I prawo fińskie było zatem właściwe do oceny dopuszczalności przeniesienia tych uprawnień na Sähköalojen ammattiliitto ry. W podobny sposób uzasadniał swoje stanowisko rzecznik generalny $N$. Wahl w opinii z 18.09.2014 r. w sprawie C-396/13, Sähköalojen ammattiliitto ry v. Elektrobudowa S.A., pkt. 55-58, 120.

${ }^{24}$ Zob. ustawę 55/2001 o umowie o pracę z 26.01.2001 r. (Työsopimuslaki). 
nywanie swoich obowiązków w Finlandii, stanowiło wynagrodzenie minimalne, o którym mowa w art. 3 ust. 1 lit. c) dyrektywy 96/71/WE w rozumieniu fińskich układów zbiorowych pracy?

Nie ulega wątpliwości, że główną powinnością pracodawcy wynikajaca ze stosunku pracy jest wypłata na rzecz swojego pracownika należnego mu wynagrodzenia ${ }^{25}$. Ze względu na sprzeczność interesów każda ze stron dąży do ustalenia tego świadczenia w wysokości dla siebie korzystnej, przy czym ich zapatrywania w tej kwestii sa rozbieżne. To z tego powodu postulat „zagwarantowania zarobku, zapewniajacego warunki przyzwoitego utrzymania” legł u podstaw Międzynarodowej Organizacji Pracy ${ }^{26}$, a „uznanie zasady "równej płacy za równą pracę»” wpisano do preambuły Konstytucji Międzynarodowej Organizacji Pracy z 9 października 1946 roku.

Wskazane powyżej zasady, na których powinny opierać się stosunki pracy, wspierane są różnymi mechanizmami, uniemożliwiającymi pracodawcom wykorzystywanie (w szczególności w okresach dekoniunktury) swojej silniejszej pozycji względem pracowników i zabezpieczającymi tych ostatnich przed wymuszaniem zgody na wynagrodzenie za pracę poniżej racjonalnie akceptowalnego poziomu. Takim instrumentem prawnym jest wprowadzana przepisami ogólnymi albo w drodze układów zbiorowych pracy minimalna wysokość płacy ${ }^{27}$ za pracę w określonym czasie lub też za uzgodniona jednostkę czasu pracy.

Wskazane powyżej wyzwanie „zagwarantowania zarobku, zapewniającego warunki przyzwoitego utrzymania" jest jeszcze bardziej palące $\mathrm{w}$ odniesieniu do pracowników delegowanych do świadczenia pracy w kraju innym niż ten, w którym zwykle wykonują swoje obowiązki. Jeżeli bowiem poziom cen dóbr i usług w państwie przyjmujacym jest wyższy niż w kraju pochodzenia, uzgodnienia stron umowy o pracę odno-

${ }^{25}$ W. Kurowski: Stosunek pracy..., s. 298; W. Kurowski, w: Prawo..., s. 703704, zob. także A.M. Świątkowski: Międzynarodowe prawo pracy, t. II, Międzynarodowe prywatne prawo pracy. Warszawa 2010, s. 299-302.

${ }^{26}$ M. Nowak: Prawo do godziwego wynagrodzenia za pracę. Regulacja prawna i treść. Łódź 2007, s. 19-40.

${ }^{27}$ Zob. wyr. TS z 18.12.2007 r., C-341/05, Laval un Partneri Ltd v. Svenska Byggnadsarbetareförbundet, Svenska Byggnadsarbetareförbundets avdelning 1, Byggettan, Svenska Elektrikerförbundet, ECLI:EU:C:2007:809, pkt 107; zob. także A.M. Świątkow ski: Kwartet Laval w prawie pracy, „Państwo i Prawo” [dalej: PiP] 2010, Nr 12, s. 38; M. No wak: Prawo do godziwego wynagrodzenia..., s. 98-146; M. Seweryński: Minimalne wynagrodzenie za prace - wybrane zagadnienia, w: Wynagrodzenie za prace $w$ warunkach spotecznej gospodarki rynkowej i demokracji, Red. W. Sa netra. Warszawa 2009, s. 53-55; K. Walczak: Pojęcie płacy godziwej w ujęciu multidyscyplinarnym, w: Prawo pracy. Refleksje i poszukiwania. Ksiega jubileuszowa Profesora Jerzego Wratnego, Red. G. Uścińska. Warszawa 2013, s. 344-345; W. Kurowski: Stosunek pracy..., s. 299. 
szące się do wysokości wynagrodzenia mogą nie uwzględniać tej różnicy, co więcej - obowiąująca w państwie pochodzenia minimalna wysokość płacy określona odpowiednimi przepisami (ustawowymi albo wynikajacymi z układów zbiorowych pracy), stanowiącymi najczęściej miarodajna legem laboris (na podstawie art. 8 ust. 2 rozporządzenia Rzym I), nie zrekompensuje konieczności wydatkowania większych środków na bieżące utrzymanie.

$\mathrm{Z}$ tych też powodów zagadnienie minimalnego wynagrodzenia za pracę w odniesieniu do pracowników delegowanych ogniskuje większość sporów na tle wykładni dyrektywy 96/71/WE ${ }^{28}$. Zgodnie z art. 3 ust. 1 lit. c) tego aktu państwa członkowskie UE zapewnia, że bez względu na to, jakie prawo stosuje się $\mathrm{w}$ odniesieniu do stosunku pracy nawiązanego przez przedsiębiorcę delegującego pracownika do innego państwa członkowskiego UE, będa gwarantowały pracownikom delegowanym na ich terytorium warunki zatrudnienia, ustalone przez przepisy powszechnie obowiązujące lub umowy zbiorowe (orzeczenia arbitrażowe) uznane za powszechnie stosowane, obejmujące m.in. minimalne stawki płacy, wraz ze stawka za nadgodziny ${ }^{29}$. Innymi słowy, pracownikowi delegowanemu do pracy na terytorium innego państwa członkowskiego UE przysługuje od swojego pracodawcy wynagrodzenie minimalne w wysokości obowiązującej na terytorium tego innego państwa ${ }^{30}$. W oczywisty sposób mechanizm ten ma zapewniać pracownikom, którzy wykonują swoje obowiązki w innym państwie niż kraj pochodzenia (ten, w którym zwykle świadczą pracę) płacę minimalną odpowiadająca realiom miejscowym, a nie państwa, z którego wyjechali. Jeżeli jednak w państwie pochodzenia obowiązuje płaca minimalna na wyższym poziomie niż w państwie przyjmującym, pracownikowi przysługuje to wyższe świadczenie (art. 3 ust. 7 dyrektywy 96/71/WE).

Stan faktyczny, który stał się kanwą dla głosowanego wyroku Trybunału Sprawiedliwości UE uwidocznił, jakie wątpliwości mogą pojawić się przy wykładni określenia „minimalne stawki płacy” z art. 3 ust. 1 lit. c) dyrektywy 96/71/WE. Chodzi tu w szczególności o precyzyjne wskazanie, które świadczenia pracodawcy na rzecz pracownika „zaliczaja” się

${ }^{28}$ Zob. P. Wą̇̇: Charakterystyka transgranicznego stosunku pracy na tle dyrektywy Nr 96/71/WE Parlamentu Europejskiego i Rady, „Monitor Prawniczy” [dalej: MoPr] 2008, Nr 2, s. 81.

${ }^{29} \mathrm{Na}$ ten temat zob. w szczególności M. Zachariasiewicz, w: System..., s. 520— 526.

${ }^{30}$ N. Reich: Free Movement $v$. Social Rights in an Enlarged Union - the Laval and Viking Cases before the ECJ, „German Law Journal” [dalej: GLJ] 2008, Nr 2, s. 142; S. Majkowska-Szulc: Sytuacja prawna pracownika delegowanego w ramach świadczenia ustug, w: Przepływ osób i świadczenie ustug $w$ Unii Europejskiej. Nowe zjawiska i tendencje, Red. S. Biernat, S. Dudzik. Warszawa 2009, s. 255-256. 
do wynagrodzenia minimalnego (a zatem sa przez nie „konsumowane”), a jakie muszą być spełniane obok niego, a co za tym idzie - podwyższają kwotę wypłacanego pracownikowi uposażenia. Co istotne, dyrektywa 96/71/WE jest w tym zakresie bardzo lakoniczna, gdyż jedynie art. 3 ust. 7 akapit drugi sugeruje, że dodatki do wynagrodzenia właściwe delegowaniu należy uważać za część płacy minimalnej, o ile nie są wypłacane z tytułu zwrotu wydatków faktycznie poniesionych na skutek delegowania, takich jak koszty podróży, wyżywienia i zakwaterowania ${ }^{31}$, a zatem te ostatnie nie moga uszczuplać minimalnej kwoty wypłacanej pracownikowi.

Punktem wyjścia dalszych rozważań powinno być stwierdzenie, że prawodawcy nie są zobowiązani do określania obowiązującego w poszczególnych państwach członkowskich UE minimalnego wynagrodzenia za pracę. Jeżeli jednak zdecyduja się na taka regulację, to „minimalna stawka płacy” może być rozmaicie przez nich kształtowana ${ }^{32}$, jak również - obejmować różne jej składniki ${ }^{33}$. Jest to materia, która podlega wewnętrznym unormowaniom prawa pracy. Jednakże, jak wcześniej wskazano, nie każde świadczenie pracodawcy może być uznane za składnik „minimalnej stawki płacy” w rozumieniu art. 3 ust. 1 lit. c) dyrektywy 96/71/WE. Dotychczasowe orzecznictwo Trybunału Sprawiedliwości UE daje przy tym podstawę do sformułowania dyrektywy ogólnej, pozwalającej wyłączyć z wynagrodzenia minimalnego te dodatki, które nie sa zdefiniowane jako składniki płacy minimalnej przez prawo lub praktykę krajową przyjmującego państwa członkowskiego UE, a dążą do zachowania równowagi między świadczeniem pracownika a otrzymywanym przez niego świadczeniem wzajemnym ${ }^{34}$. Innymi słowy, jeżeli pracodawca wymaga od pracownika świadczenia pracy w warunkach, wymiarze, czy też okolicznościach przekraczających wymagania stawiane w normalnym biegu rzeczy, to taki zwiększony wysiłek pracownika po-

${ }^{31}$ Zob. P. Wąż: Glosa do wyroku TS z dnia 12 lutego 2015 r., C-396/13, LEX/el. 2015 , pkt 3.

${ }^{32}$ Zob. wyr. TSUE z 7.11.2013 r., C-522/12, Tevfik Isbir v. DB Services GmbH, ECLI:EU:C:2013:711, pkt 36. Zob. także P. Wą̇̇: Dyrektywa Nr 96/71/WE w orzecznictwie Trybunału Sprawiedliwości, MoPr 2008, Nr 11, s. 577.

${ }^{33}$ Zob. m.in. wyr. Tryb. EFTA z 23.1.2012 r., E-2/11, STX Norway Offshore AS v. Norwegia, niepubl., pkt 61, 64.

${ }^{34}$ Zob. wyr. TSUE z 14.4.2005 r., C-341/02, Komisja Wspólnot Europejskich v. Republika Federalna Niemiec, ECLI:EU:C:2005:220, pkt 39-40 oraz wyr. TSUE z 7.11.2013 r., C-522/12, Tevfik Isbir v. DB Services GmbH, ECLI:EU:C:2013:711, pkt 38-40. Zob. także P. Wąż, Glosa do wyroku TS z dnia 12 lutego 2015 r., C-396/13, LEX/el. 2015, pkt 3; M. Zachariasiewicz, w: System..., s. 525-526. 
winien być dodatkowo wynagradzany ponad „minimalna stawkę płacy”, o której mowa w art. 3 ust. 1 lit. c) dyrektywy 96/71/WE ${ }^{35}$.

W sprawie z powództwa Sähköalojen ammattiliitto ry przeciwko Elektrobudowie S.A. związek zawodowy zakwestionował zasadność zaliczenia do „minimalnej stawki płacy” wypłaconych pracownikom: a) stałej diety należnej w związku z delegowaniem do świadczenia pracy poza swoim miejscem zamieszkania, b) dodatku wakacyjnego, c) odszkodowania za utratę czasu potrzebnego na dojazd do miejsca świadczenia pracy, oraz wartości przekazanych przez pracodawcę: d) bonów na posiłki, a także ponoszonych za pracowników: e) kosztów ich zakwaterowania.

Poza wątpliwościami dotyczącymi wykładni określenia „minimalnej stawki płacy”, którym posłużył się prawodawca w art. 3 ust. 1 lit. c) dyrektywy 96/71/WE, dodatkowe zarzuty Sähköalojen ammattiliitto ry wobec Elektrobudowie S.A. wiązały się z uniemożliwieniem pracownikom pracy na akord (przez co nie mogli osiągnać wyższego wynagrodzenia), jak również z niekorzystnym dla pracowników zaliczeniem ich do kategorii zaszeregowania zgodnie z prawem, któremu podlegała umowa o pracę (prawem polskim), a nie na podstawie prawa państwa przyjmującego (fińskich układów zbiorowych pracy).

Odnosząc się do pytania, czy stała dieta wypłacana pracownikom $\mathrm{w}$ związku z delegowaniem do świadczenia pracy poza swoim miejscem zamieszkania stanowi część płacy minimalnej, Trybunał Sprawiedliwości UE opowiedział się za uznaniem tak określonego dodatku za jeden z elementów tego wynagrodzenia, na warunkach zbieżnych do tych, na jakich ta dieta właczana jest do płacy minimalnej wypłacanej pracownikom lokalnym w przypadku ich delegowania w ramach danego państwa członkowskiego UE. Sąd słusznie uznał stała dietę za „dodatek właściwy delegowaniu" w rozumieniu art. 3 ust. 7 akapit drugi dyrektywy 96/71/WE, gdyż nie jest on wypłacany z tytułu zwrotu wydatków faktycznie poniesionych na skutek delegowania, takich jak koszty podróży, wyżywienia i zakwaterowania. Zgodnie bowiem z mającymi do sprawy zastosowanie układami zbiorowymi pracy, stała dieta stanowiła kwotę ryczałtową (34-36 euro), wypłacaną za każdy dzień delegowania poza określone umową miejsce świadczenia pracy. Był to zatem dodatek majacy na celu zrekompensowanie niedogodności, jakie wiążą się z koniecznościa przebywania poza swoim miejscem zwykłego pobytu ${ }^{36}$. Nie miał

${ }^{35}$ Zob. S. Majkowska-Szulc: Sytuacja prawna..., s. 255-256.

${ }^{36}$ Tak TSUE wyr. z 12.2.2015 r., C-396/13, Sähköalojen ammattiliitto ry v. Elektrobudowa SA, ECLI:EU:C:2015:86, pkt 49-51, odmiennie $N$. Wahl w opinii rzecznika generalnego z 18.9.2014 r. w sprawie C-396/13, Sähköalojen ammattiliitto ry v. Elektrobudowa SA, ECLI:EU:C:2014:2236, pkt 100. 
on natomiast na celu wyrównanie zwiększonych kosztów (zwrotu wydatków) faktycznie poniesionych na skutek delegowania.

Trybunał Sprawiedliwości UE nie miał także wątpliwości co do uznania dodatku wakacyjnego, wypłacanego pracownikom zgodnie z prawem państwa przyjmującego w okresie płatnego urlopu, za element kształtujący „minimalną stawkę płacy” w myśl art. 3 ust. 1 lit. c) dyrektywy 96/71/WE. W tym przypadku sąd słusznie przyją, że skoro każdemu pracownikowi przysługuje coroczny płatny urlop, to powiąane z nim świadczenie należne jest także pracownikom delegowanym. Realizacja koncepcji płatnego urlopu ma bowiem zapewniać pracownikowi będaceemu na urlopie sytuację zbieżna — w odniesieniu do wynagrodzenia - do tej, w jakiej znajduje się on w okresach wykonywania pracy ${ }^{37}$.

Kolejne pytanie kierowane do Trybunału Sprawiedliwości UE dotyczyło odszkodowania za czas potrzebny na dotarcie do pracy i dopuszczalności uznania tego świadczenia za element „minimalnej stawki płacy", w rozumieniu art. 3 ust. 1 lit. c) dyrektywy 96/71/WE.

$\mathrm{W}$ tym przypadku sad - podobnie jak to uczynił w odniesieniu do stałej diety $\mathrm{w}$ związku z delegowaniem - uznał, że odszkodowanie to nie jest wypłacane tytułem zwrotu wydatków faktycznie poniesionych na skutek delegowania, zgodnie z art. 3 ust. 7 akapit drugi dyrektywy 96/71/WE, a w związku z tym należy je traktować jako dodatek właściwy delegowaniu, a tym samym jako składnik minimalnego wynagrodzenia za prace $e^{38}$. Dodatek ten nie stanowił bowiem odszkodowania sensu stricto, uzależnionego od wysokości szkody. Mimo mylącej nazwy, zgodnie fińskim z układem zbiorowym pracy, stanowił on bowiem świadczenie pracodawcy majace kompensować wydłużony dojazd do miejsca wykonywania obowiązków pracowniczych (przewyższający dziennie godzinę) i przybierał formę ryczałtu.

W przypadku trzech opisanych powyżej dodatków do wynagrodzenia, Trybunał Sprawiedliwości UE uznał, że kształtują one (a zatem - wchodzą w zakres) „minimalnej stawki płacy” w rozumieniu art. 3 ust. 1 lit. c) dyrektywy $96 / 71 / \mathrm{WE}^{39}$. Nie zostały one bowiem uznane za świadcze-

${ }^{37}$ Tak TSUE w wyr. z 16.3.2006 r., C-131/04 i C-257/04, C. D. Robinson-Steele v. R. D. Retail Services Ltd oraz Frank Staddon Ltd, J. C. Caulfield, C. F. Caulfield, K. V. Barnes v. Hanson Clay Products Ltd, EU:C:2006:177, pkt 58; TSUE w wyr. z 20.1.2009 r., C-350/06 i C-520/06, Gerhard Schultz-Hoff v. Deutsche Rentenversicherung Bund oraz Stringer v. Her Majesty's Revenue and Customs, EU:C:2009:18, pkt 60; TSUE w wyr. z 22.5.2014 r., C-539/12, Z.J.R. Lock v. British Gas Trading Limited, EU:C:2014:351, pkt 17.

38 Tak TSUE w wyr. z 12.2.2015 r., C-396/13, Sähköalojen ammattiliitto ry v. Elektrobudowa SA, ECLI:EU:C:2015:86, pkt 56.

${ }^{39}$ Zob. P. Wąż: Glosa do wyroku TS z dnia 12 lutego 2015 r., C-396/13, LEX/el. 2015 , pkt 5 . 
nia wypłacane $\mathrm{z}$ tytułu zwrotu wydatków faktycznie poniesionych na skutek delegowania, takich jak koszty podróży, wyżywienia i zakwaterowania (art. 3 ust. 7 akapit drugi dyrektywy 96/71/WE) oraz nie mają na celu dyskryminowanie zagranicznych usługodawców, co byłoby sprzeczne $\mathrm{z}$ art. 56 TFUE (dodatki nie moga bowiem przysługiwać jedynie pracownikom delegowanym z innych krajów) ${ }^{40}$.

Poza zagadnieniem kształtowania minimalnego wynagrodzenia za pracę poprzez dodatkowe świadczenia pieniężne spełniające kryteria określone w cytowanym powyżej art. 3 ust. 7 akapit drugi dyrektywy 96/71/WE, Trybunał Sprawiedliwości UE podjął także kwestię dopuszczalności zaliczania przez pracodawcę na poczet kwoty wcześniej ustalonej pensji korzyści niepieniężnych uzyskiwanych przez pracowników. W sprawie Sähköalojen ammattiliitto ry przeciwko Elektrobudowie S.A. przedmiotem sporu stało się uwzględnianie przy wypłacaniu „minimalnej stawki płacy” w rozumieniu art. 3 ust. 1 lit. c) dyrektywy wartości przekazanych przez pracodawcę bonów na posiłki, a także ponoszonych za pracowników kosztów ich zakwaterowania. Także i w tym przypadku kluczem do odpowiedzi na wskazane pytanie stała się dokonana przez Trybunał Sprawiedliwości UE wykładnia przepisu art. 3 ust. 7 akapit drugi dyrektywy 96/71/WE. Punktem wyjścia było założenie, że celem wskazanej regulacji jest zabezpieczenie pracowników przed niesłusznym zaliczaniem przez pracodawcę na poczet wypłaty minimalnego wynagrodzenia za pracę niepieniężnych świadczeń pracodawców na rzecz swoich pracowników, które w rzeczywistości pokrywają dodatkowe koszty, jakie ci ostatni ponosiliby $\mathrm{w}$ związku $\mathrm{z}$ ich delegowaniem do pracy $\mathrm{w}$ innym państwie. Inaczej bowiem dochodziłoby do pomniejszania kwoty „minimalnej stawki płacy”, stanowiącej ekwiwalent za świadczona pracę, o sumy wydatkowane na pokrycie zobowiąań, które po stronie pracownika wyniknęły z powodu delegowania. W kraju, w którym zwykle wykonuja oni swoje obowiązki na podstawie umowy o pracę (tj. najczęściej tam, gdzie ześrodkowana jest ich aktywność życiowa), nie ponoszą przecież tych dodatkowych kosztów - podróży (pomiędzy miejscem gdzie aktualnie pracownik wykonuje swoje obowiązki a państwem, w którym zwykle świadczy pracę), zakwaterowania (poza kosztami związanymi z utrzymaniem dotychczasowego, stałego lokalu, gdzie dotychczas mieszkał (a najczęściej dalej mieszka jego rodzina) pracownik musi bowiem zapewnić sobie zakwaterowanie na czas delegowania) oraz wyżywienia (które z reguły są wyższe poza miejscem stałego zamieszkania).

${ }^{40}$ Tak N. Wahl w opinii rzecznika generalnego z 18.09.2014 r. w sprawie C-396/13, Sähköalojen ammattiliitto ry v. Elektrobudowa SA, ECLI:EU:C:2014:2236, pkt 93. 
W przypadku polskich pracowników delegowanych przez Elektrobudowę S.A. do pracy w Finlandii, pracodawca podją się zorganizowania i opłacania zakwaterowania tych osób w okresie, w którym wykonywali obowiązki pracownicze za granica. Co więcej, Elektrobudowa S.A. finansowała także (przynajmniej w części) wyżywienie swoich pracowników, dystybuujac nieodpłatnie bony żywnościowe na ich rzecz. Świadczenia te nie były zatem wprost „zwrotem wydatków faktycznie poniesionych na skutek delegowania" w rozumieniu art. 3 ust. 7 akapit drugi dyrektywy 96/71/WE, gdyż pracownicy wcześniej takich obciążeń nie doznali. W konsekwencji nie powinny być one uznawane za element płacy minimalnej, do której pracownicy delegowani byli uprawnieni, co za tym idzie — ich wartość mogłaby pomniejszać sumę „minimalnej stawki płacy”, jaka mieli oni otrzymać (wynagrodzenie realnie wypłacone w powiazaniu z wartością tych niepieniężnych świadczeń stanowiłoby kwotę „minimalnej stawki płacy”, o której mowa w art. 3 ust. 1 lit. c) dyrektywy 96/71/WE).

Takiej, korzystnej dla pracodawców, wykładni art. 3 ust. 7 akapit drugi dyrektywy nie dokonał tak rzecznik generalny ${ }^{41}$, jak i Trybunał Sprawiedliwości UE ${ }^{42} \mathrm{w}$ swoim orzeczeniu. Zorganizowanie zakwaterowania dla swoich pracowników oraz zapewnienie darmowych posiłków przez pracodawcę należy — ich zdaniem - uznać za swoiście rozumiany „zwrot wydatków faktycznie poniesionych na skutek delegowania”. Nie jest bowiem istotne, $\mathrm{w}$ jakim czasie i w jaki sposób pracownik uzyska świadczenie ściśle powiąane $\mathrm{z}$ delegowaniem do pracy $\mathrm{w}$ innym kraju ${ }^{43}$. Kluczową kwestia jest natomiast, że ów pracownik nie powinien ze środków stanowiących „minimalną stawkę płacy”, o której mowa w art. 3 ust. 1 lit. c) dyrektywy 96/71/WE, finansować wydatków, których nie musiałby pokryć, świadcząc pracę w miejscu, gdzie zwykle wykonuje on swoje obowiązki. Przyjmujac odmienną optykę, łatwo byłoby zniweczyć ratio legis omawianej regulacji. Świadczenia rekompensujące zwiększenie kosztów ponoszonych przez pracownika w związku z delegowaniem, obniżałyby bowiem wysokość wynagrodzenia poniżej dopuszczalnego minimum. Reasumując, rzeczowe świadczenia związane z podróżą, wyżywieniem i zakwaterowaniem powinny być zawsze uznawane za „dodatki właściwe delegowaniu”, które „należy uważać za część płacy minimalnej”

${ }^{41}$ Tak N. Wahl w opinii rzecznika generalnego z 18.09.2014 r. w sprawie C-396/13, Sähköalojen ammattiliitto ry v. Elektrobudowa SA, ECLI:EU:C:2014:2236, pkt. 114, 120.

${ }^{42}$ Tak TS w wyr. z 12.02.2015 r., C-396/13, Sähköalojen ammattiliitto ry v. Elektrobudowa SA, ECLI:EU:C:2015:86, pkt. 58-63.

${ }^{43}$ Tak też P. Wąż: Glosa do wyroku TS z dnia 12 lutego 2015 r., C-396/13, LEX/el. 2015 , pkt 5 . 
w rozumieniu art. 3 ust. 1 lit. c) dyrektywy 96/71/WE (a zatem za nieobniżające jej wysokości).

O ile wykładnia przepisów art. 3 ust. 1 lit. c) oraz art. 3 ust. 7 akapit drugi dyrektywy 96/71/WE, dokonana przez Trybunał Sprawiedliwości UE, wydaje się logiczna, w szczególności w odniesieniu do sposobu interpretacji wyrażenia „zwrot wydatków faktycznie poniesionych na skutek delegowania, takich jak koszty podróży, wyżywienia i zakwaterowania" w kontekście ich prefinansowania przez pracodawce w postaci zapewnienia darmowego zakwaterowania pracowników delegowanych za granica, czy też nieodpłatnej dystrybucji bonów żywnościowych, o tyle przyjęte przez sąd stanowisko odnośnie do sposobu zaszeregowania pracowników, który wpływa na wysokość otrzymywanego przez nich wynagrodzenia, zasługuje na krytykę.

Co prawda, zagadnienie zaszeregowania pracowników do określonych grup nie dotyczy wprost kwestii „minimalnej stawki płacy”, o której mowa w art. 3 ust. 1 lit. c) dyrektywy 96/71/WE, lecz w sprawie będącej przyczynkiem do rozstrzygnięcia przez Trybunał Sprawiedliwości UE, owo (niewłaściwe - zdaniem tego sądu) zaszeregowanie miało znaczenie dla ustalenia minimalnego wynagrodzenia danych pracowników. Wskazane na wstępie zagadnienie - przyporządkowania danego pracownika do określonej ich grupy, ze wskazaniem stawki wynagrodzenia jej przypisanej, należy niewątpliwie do zakresu statutu stosunku pracy, wyznaczanego zgodnie $\mathrm{z}$ regułami kolizyjnymi wynikajacymi z art. 8 rozporządzenia Rzym I. Nie zostało ono jednak — jak inne, w szczególności maksymalne okresy pracy i minimalne okresy wypoczynku, minimalny wymiar płatnych urlopów rocznych, czy też omawiane w tej glosie minimalne stawki płacy - wymienione w art. 3 ust. 1 dyrektywy 96/71/WE, co pozwalałoby w odniesieniu do pracowników delegowanych na sięgnięcie do prawa państwa przyjmującego, jeżeli przewidywałoby ono warunki pracy lub płacy korzystniejsze niż wynikające z prawa, któremu podlega umowa o pracę tych osób. Innymi słowy, prawodawca unijny w kwestii zaszeregowania pracowników do określonej grupy nie przyznał prawu państwa, na terytorium którego pracownik delegowany wykonuje (tymczasowo) swoje obowiązki, kompetencji do jego kształtowania w sposób odmienny od przyjętego $\mathrm{w}$ statucie stosunku pracy ${ }^{44}$. Nie przeszkodziło to jednak Trybunałowi Sprawiedliwości UE uznać, że co do pracowników delegowanych powinny znaleźć zastosowanie przepisy państwa przyjmujaccego, które przypisuja pracowników do określonych grup zaszeregowania w sposób pozwalajaccy im uzyskać wynagrodzenie wyższe,

${ }^{44}$ Tak też P. Wąż: Glosa do wyroku TS z dnia 12 lutego 2015 r., C-396/13, LEX/el. 2015 , pkt 4 . 
niż by to wynikało z klasyfikacji poddanej statutowi stosunku pracy ${ }^{45}$. In concreto chodziło o umożliwienie pracownikom Elektrobudowy S.A., delegowanym do pracy w Finlandii, pracy na akord (lepiej wynagradzanej, ze swoja „minimalną stawkę płacy”), czego nie przewidywało prawo dla ich umów o pracę właściwe (prawo polskie), zamiast pracy w oparciu o godzinową „minimalną stawką płacy” (mniej dla pracowników korzystną). Sähköalojen ammattiliitto ry stał na stanowisku, że pracodawca miał obowiązek zaoferowania swoim pracownikom pracy na akord (a co za tym idzie - wypłacenia specjalnego wynagrodzenia z tym związanego). Jedynymi ograniczeniami stosowania przepisów prawa państwa przyjmujacego $\mathrm{w}$ tym przypadku miałyby być: ich „wiążący” charakter (a zatem powinny być powszechnie obowiązujace lub też wynikać z układów zbiorowych pracy) oraz spełnianie przez te przepisy wymogów przejrzystości (a zatem muszą być one dostępne i jasne). Tymczasem w świetle dyrektywy 96/71/WE brak jest podstaw prawnych do takiego stanowiska. Przepisy tego aktu nie nakładaja na pracodawce obowiąku stosowania regulacji państwa przyjmujacego przewidujaccych dla pracowników „wyższe” albo „najwyższe” minimalne wynagrodzenie za pracę, jeżeli zgodnie z tym prawem istnieje alternatywne do podstawowego unormowanie „minimalnej stawki płacy”46. Dyrektywa nie znajduje poza tym zastosowania w kwestii zaszeregowania pracowników do określonej kategorii, a zatem brak jest podstaw do stosowania zasad przyjętych w tym zakresie w prawie państwa przyjmujaccego. Jak się wydaje, Trybunał Sprawiedliwości UE, pomijając stanowisko rzecznika generalnego ${ }^{47}$, odszedł przy wydawaniu omawianego orzeczenia od założenia, którym się kierował wcześniej w podobnej sytuacji, by oceniając zagadnienie minimalnego wynagrodzenia za pracę pracowników delegowanych nie doprowadzać do maksymalizacji „minimalnej stawki płacy” na tle dyrektywy 96/71/WE ${ }^{48}$. W uzasadnieniu orzeczenia Trybunału Sprawiedliwości UE wybrzmiewa przy tym teza, że „płaca minimalna obliczona poprzez odniesienie do odpowiednich układów zbiorowych pracy (szerzej mówiąc — prawa państwa przyjmującego) nie może zależeć od swobodnego wy-

${ }^{45}$ Odmiennie $N$. Wahl w opinii rzecznika generalnego z 18.09.2014 r. w sprawie C-396/13, Sähköalojen ammattiliitto ry v. Elektrobudowa SA, ECLI:EU:C:2014:2236, pkt 81.

${ }^{46}$ Zob. P. Wąż: Glosa do wyroku TS z dnia 12 lutego 2015 r., C-396/13, LEX/el. 2015, pkt 4 .

${ }^{47}$ Zob. N. Wahl w opinii rzecznika generalnego z 18.09.2014 r. w sprawie C-396/13, Sähköalojen ammattiliitto ry v. Elektrobudowa SA, ECLI:EU:C:2014:2236, pkt. 81-83.

${ }^{48}$ Zob. wyr. TSUE z 18.12.2007 r., C-341/05, Laval un Partneri Ltd v. Svenska Byggnadsarbetareförbundet, Svenska Byggnadsarbetareförbundets avdelning 1, Byggettan, Svenska Elektrikerförbundet, ECLI:EU:C:2007:809, pkt 71. 
boru pracodawcy delegującego pracowników wyłącznie w celu oferowania kosztu pracy niższego niż w przypadku pracowników lokalnych"49.

Orzeczeniem w sprawie C-396/13 Trybunał Sprawiedliwości UE poszedł jeszcze o krok dalej w propracowniczej wykładni dyrektywy 96/71/ WE. Pomijajac bowiem doprecyzowanie tym wyrokiem przesłanek dopuszczalności zaliczenia niektórych kategorii dodatków do wynagrodzenia jako elementów „minimalnej stawki płacy”, o której mowa w art. 3 ust. 1 lit. c) dyrektywy 96/71/WE, sąd ten przesądził możliwość uznania rzeczowych świadczeń związanych z podróża, wyżywieniem i zakwaterowaniem (po spełnieniu określonych warunków) za „dodatki właściwe delegowaniu”, które „należy uważać za część płacy minimalnej” w rozumieniu tej dyrektywy (a zatem nie obniżaja jej wysokości). Co jednak najistotniejsze, a w świetle dyrektywy 96/71/WE, raczej niesłuszne, Trybunał Sprawiedliwości UE opowiedział się za koniecznością stosowania przez pracodawców systemów wynagradzania oraz sposobów zaszeregowania delegowanych pracowników zgodnie z regułami wynikającymi z prawa państwa przyjmującego (w tym także - układów zbiorowych pracy).

${ }^{49}$ Tak TSUE w wyr. z 12.02.2015 r., C-396/13, Sähköalojen ammattiliitto ry v. Elektrobudowa SA, ECLI:EU:C:2015:86, pkt 41. 